\title{
Ormancılık ve Orman Ürünleri Programı Öğrencilerinin Staj Yapma Eğilimlerinin Belirlenmesi: Uşak Üniversitesi Örneği
}

\author{
Abdurrahman Karamana ${ }^{a *}$ Ahmet Erkan Metin ${ }^{b}$, Şahser Güvenc \\ a,b,c Uşak Üniversitesi, Banaz Meslek Yüksekokulu, Uşak
}

\section{$\ddot{O} z$}

Mesleki ve teknik eğitim öğretimin yapıldığı kurumlarda staj, ön lisans düzeyinde öğrenim gören öğrencilere deneyim ve beceri kazandırmanın en önemli yoludur. Ayrıca staj hem öğrencilerin iş ortamın tanıma, teorik ve uygulama bilgilerini karşılaştırma, mesleki deneyimlerini artırmak hem de kurum ve kuruluşların nitelikli ara elaman ihtiyaçlarına katkı sağlamaktadır. Bu çalı̧mada, Uşak Üniversitesi Banaz Meslek Yüksekokulu Ormancılık ve Orman Ürünleri programında öğrenim gören öğrencilerinin yaz stajı eğitimine yönelik görüşlerinin belirlenmesi ve elde edilen sonuçlar çerçevesinde mevcut sorunlara, staj verimliliğini arttırmaya yönelik bir takım öneriler geliştirilmesi amaçlanmıştır. Araştırma materyali olarak, Uşak Üniversitesi Banaz Meslek Yüksekokulu Ormancllı ve Orman Ürünleri programı öğrencileri arasından kolayda örnekleme yöntemi ile 81 tanesi seçilmiştir. Bu öğrencilere anket uygulanmıştır. Anket çalışması 2 bölümden oluşmaktadır. Birinci bölümde öğrencilerin demografik yapı ve staj yeri ile ilgili bilgileri, ikinci bölümde ise stajın önemi ve işleyişi ile ilgili 5'li Likert tipi sorular bulunmaktadır. Öğrencilerden, sorularn cevaplandırırken, her bir bölümde yer alan soruya önem derecelerine göre en uygun cevabı vermeleri istenmiştir. Sonuç olarak öğrencilerin staj yapılması hakkında eğilimleri ortaya konulmuştur. Öğrencilerin, stajda mesleki becerilerini kullanma imkânı bulduklarını, problemleri görme çözme imkânı bulduklarını ve mesleki alanda takım çalışmasına katıldıklarını belirtmişlerdir. Staj yapan öğrencilerin büyük bir çoğunluğunun stajdan olumlu sonuçlar aldığı araştırma sonucunda görülmüştür.

Anahtar Kelimeler: Staj Ĕ̆itimi, Meslek Yüksekokulu, Ormancılık Bölümü.

\section{Determination of Forestry Program Students' Tendency of Internship Training: Usak University Case}

\section{Abstract}

At institutions where vocational and technical education is provided, it is the most important way of gaining experience and skills for students at undergraduate level. The internship is aimed at defining the business environment of the students, comparing the theoretical and practical knowledge, increasing their professional experience and contributing to the needs of qualified intermediaries of institutions and organizations. In this study, it was aimed to determine the opinions of the students of Uşak University Banaz Vocational School Forestry and Forestry program on the summer internship education and to develop some suggestions for existing problems and increasing internship productivity in the framework of the results obtained. As the research material, 81 people were selected easy sampling method among the students of Uşak University Banaz Vocational School Forestry and Forestry program. A questionnaire was applied to these students. The questionnaire consists of two parts. The first part deals with the demographic structure and the internship place of the students and the second part has the Likert with five type questions about the importance and the function of the 
internship. When students answer the questions, they are asked to answer the questions in each section according to their importance. As a result, the tendencies of the students about the internship were revealed. During the internship, students stated that they had the opportunity to apply the theoretical training they had received, they could have an idea about directing their future work life, the internships contribution to the development of the confidence of theirselves, and they got the opportunaty to participate in the professional field team work. As the result of the research; a large majority of students who took internships were found to be received positive results from the internship.

Keywords: Internship Education, Vocational School, Department of Forestry.

\section{Gíriş}

Türkiye'de yükseköğretim düzeyinde, nitelikli insan gücünün yetiştirilebilmesi için en önemli eğitim kurumlarından birisi de meslek yüksekokullarıdır. Günümüzde iki yıllık eğitim programları doğrultusunda meslek eğitimi veren bu kurumların temel amacı, iş yaşamının gereksinim duyduğu, bilimsel ve teknolojik gelişmelere uyum sağlayabilecek ve kaliteli üretimi gerçekleştirebilecek yüksek nitelikli ara insan gücünün yetiştirilmesini sağlamaktır. Mezunlarının tekniker unvanı aldığı meslek yüksekokullarında öğrenim gören öğrencilerin, teknisyenlerden daha fazla teorik bilgiye, mühendislerden ise daha fazla uygulama becerisine sahip olabilmeleri amaçlanmaktadır.

Türkiye'deki mevcut devlet meslek yüksekokulları eğitim programlarında akademik eğitim ağırlıklı bir program uygulanmaktadır. Eğitim programları içerisinde "Staj" olarak adlandırılan ve mezun olunabilmesi için zorunlu kılınan bu zaman diliminde öğrenciler belirli dönemlerde 30 işgünü boyunca, öğrenim gördükleri programla ilgili kamu ve özel sektörde staj öğrenimlerine devam etmektedirler.

Staj çalışmaları öğrencilere yüksekokulda almış oldukları bilgi, beceri ve alışkanlıklarını gerçek ortamda gözlemlemesi ve uygulamasına olanak sağlamaktadır. Ancak, staj çalışmalarının başarılı olabilmesi için mutlaka konusunda uzman öğretim elemanları tarafından denetlenmesi gerekmektedir (MEB-YÖK Meslek Yüksekokulları Program Geliştirme Projesi, 2002). Staj çalışmaları MEB-YÖK Meslek Yüksekokulları Program Geliştirme Projesi kapsamında geliştirilen ve Gerek öğrencilerin öğrenim süresince edindikleri teorik bilgilerin iş hayatında pratiğe aktarılmasında, gerekse iş hayatı öncesinde mesleki tecrübeler kazanmaları ve sektörün beklentilerini görerek buna göre hazırlıklı olmalarını sağlayan staj uygulamaları öğrenim sürecinin önemli bir parçasıdır. Aynı zamanda staj eğitimi, öğrencilerin meslek yüksekokullarından mezun olabilmeleri için yerine getirmeleri zorunlu şartlardan biridir (Karacan, ve Karacan 2004, 169). Staj faaliyetlerinin önemi, öğrenci ile işyerindeki çalışanlar arasında karşılıklı bilgi alışverişi (işe dayalı öğrenme) ortamının oluşmasında yatmaktadır.

Staj çalışmaları, eğitim-öğretim programının temel öğelerindendir. Amaç, staj yapan öğrencilerin, akademik olarak kazandıkları bilgi ve becerileri gerçek yaşam ortamında pekiştirebilmeleridir. Ayrıca, sektördeki yeni gelişmeleri, ilgili teknolojinin 
kullanımını ve faklı işyerlerini tanıma şansı bulmaları da hedeflenir. Bu konuda yapılan araştırmalar, eğitimcilere öğrencilerin staj çalışmaları süresince hangi derslerden daha çok yararlandıklarını, hangilerinden en az yararlandıklarını, hangi konuların ilgili ders içeriklerine eklenmesi ve ne gibi yeni derslerin eğitim-öğretim programına alınması gerektiğine ilişkin önerileri yapabilmelerine olanak vermektedir (Çetin, 2005).

Bu araştırmada, Uşak Üniversitesi, Banaz Meslek Yüksekokulu, Ormancılık ve Orman Ürünleri Programı I.ve II. öğretimde öğrenim gören 2. sinıf öğrencilerinin staj eğitimi uygulamaları hakkındaki olumlu ve olumsuz görüşlerini tespit etmek; katılımcıların memnuniyet duydukları durumlara ilişkin görüşlerini saptamak, memnuniyetsizlik yaşadıkları durumları inceleyip staj verimliliğini arttırmaya yönelik öneriler geliştirilmesi amaçlanmaktadır Araştırma bulgularının, ilgili literatüre katkı sağlamasının yanı sıra, diğer Meslek Yüksekokulları için yol gösterici olması beklenmektedir.

\section{Literatür Taraması}

İşe dayalı öğrenmede öncelikle iş yerindeki yeni bilgiler, öğrencinin daha önce okulda öğrendikleriyle bütünleşmekte, öğrenilenler gerçek iş yaşamında uygulanmak suretiyle anlam kazanmaktadır (Doğan vd., 1997: 191). Staj, kuramsal meslek bilgisine sahip kişilerin, aldıkları akademik bilgileri gerçek yaşamda kullanma ve deneme, diğer bir deyişle, edindiği bilgileri yaparak-yaşayarak davranışa dönüştürme deneyimi biçiminde tanımlanabilir. Staj, kişiye ayrıca, iş yaşamına ilişkin sorunları tanıma, onlarla başa çıkma, iş arkadaşları ve üstleri ile iyi iletişim kurabilme, konukları tanıma ve onların neler beklediklerini gözlemleme ve onlarla nasıl sağlıklı iletişim kurulacağına ilişkin çok değerli bilgiler kazandırır. Kişi kendini daha donanımlı hisseder ve kişinin öz güveni gelişir. Sektöre ait yenilikleri tanıma yanında, mezuniyet sonrası için önemli bir referans elde edilmiş olur (Çetin, 2005: 154). Stajlar çoğu öğrenci için çalışma hayatı ile tanıştıkları ilk dönem olmaktadır. Öğrencilerin sektörü ve mesleği sevmelerinde staj döneminin önemli rolü ve işlevi bulunmaktadır. Yapılan araştırmalar gösteriyor ki, öğrencileri gelecekte sektörde çalışma veya çalışmama düşüncesine yönelten en önemli etkiler staj döneminde ortaya çıkmaktadır (Taşkın, 2006). Mesleki eğitim alan kişilerin teorik olarak öğrendikleri bilgileri meslek yaşamlarında kullanabilmeleri için gerekli olan becerileri de eğitimleri sürecinde geliştirmeleri gerekmektedir. Öğrencilerin eğitim süresi içinde teoride edindiği bilgilerde pratiklik kazanması iki şekilde sağlanabilmektedir. Bunlardan birincisi, uygulama derslerinde okulun uygulama birimlerinde yapacağı uygulamalar, ikincisi de kurumlarda yapacağı stajlardır (Emir vd., 2008: 276). Öğrencilerin staj dönemleri mesleki kariyerleri açısından önemli karar noktalarından biri durumundadır. Öğrencilerin mezun olduktan sonra sektörde çalışmaya devam etmeleri staj uygulamalarının başarılı bir eğitim sürecinden geçtiğini göstermektedir. Stajın etkin bir şekilde gerçekleşmesi ve öğrencilerin staja olan bakış açılarının değiştirilmesinde staj yerinin ve staj danışmanın davranışlarının önemli bir etki sağladığını göstermektedir (Bahadır ve Oğuz, 2012). Öğrencilerin staj etkinliklerinden beklenen yararın sağlanması için staj yapan öğrencilerin iş yerlerinde yeterince denetlenmesi ve stajyer 
öğrencilere geçici eleman gözüyle bakılıp stajyerlik konusunun önemsenmediği gerekçesiyle iş yerlerinde staj eğitiminin önemi konusunda bilgilendirme çalışmalarının yapılmasını belirtmektedir (Aydemir, 2016). Öğrencileri sektöre hazırlayan öğretim elemanları, sektörün talep ve ihtiyaçlarını doğru analiz ederek eğitim müfredatını sürekli iyileştirebilmelidir. Ayrıca öğretim elemanları sektör temsilcileri ile belli periyotlarda bir araya gelerek, sektörün işgücü sorunlarını en aza indirebilecek çalışmalarda bulunabilmelidir. Özellikle staj eğitiminin başarılı olabilmesi için öğretim elemanları koordinatörlük (danışmanlık) görevlerini tam anlamıyla yapılmasını belirtmektedir (Tekbalkan, 2015).

\section{Materyal ve Yöntem}

Araştırma materyali olarak, Uşak Üniversitesi Banaz Meslek Yüksekokulu ormancılık ve orman ürünleri programı öğrencileri arasından kolayda örnekleme yöntemi ile 81 öğrenci seçilmiştir. Araştırmada birçok verinin elde edilebilmesi için anket (soru sorma tekniği kullanılmıştır. Bu öğrencilere toplam 26 ölçekten oluşan anket uygulanmıştır. Anket çalışması 2 bölümden oluşmaktadır. Birinci bölümde 6 soruluk öğrencilerin demografik yapı ve staj yeri ile ilgili bilgileri (cinsiyet, yaş, aile ile ikamet edilen bölge, mezun olunan lise türü, staj yapılan bölge ve okunan programin tercih edilme nedeni), yer alırken, ikinci kısımda ise katılımcıların staj uygulamasına ilişkin düşüncelerini ortaya koymak için 20 ifade yer almaktadır. Anket soruları oluşturulurken daha önce yapılmış çalışmalardan (Demir, 2001; Şimşek ve Çetinkaya, 2004; Karacan 2004; Pelit ve Güçer, 2006; Bahadır ve Oğuz 2012; Hsu, 2012; Aymankuy vd., 2013; Dilay vd., 2015) yararlanılmıştır. Bu ifadelerin değerlendirilmesinde 5'li likert ölçeği (1: Hiç katılmıyorum, 2: Katılmıyorum, 3: Kısmen Katılıyorum, 4: Katılıyorum, 5: Tamamen katılıyorum) öğrencilerin staj uygulamasına ilişkin düşünceleri ölçülmeye çalışılmıştır.

Araştırma evreninde yer alan öğrenci sayısı kadar çoğaltılıp dağıtılan anketler değerlendirmeye alınmıştır. Ölçeğin güvenirliğini belirlemek amacıyla “güvenirlik analizi" uygulanmıştır. Bu kapsamda Croncbach Alpha katsayısı 0,91 çıkmıştır. Bu sonuç ölçeğin yüksek derecede güvenilir olduğunu göstermektedir. Öğrencilerin hem demografik özelliklerine ilişkin sonuçlar hem de ölçeğe ilişkin sorular için frekans ve yüzde dağılımları, aritmetik ortalamaları ve standart sapma değerleri hesaplanarak tablolar halinde verilmiştir. Bu testlerin uygulanmasında SPSS 20.0 (Statistical Package for Social Science) paket programından yararlanılmıştır.

\section{Bulgular}

Ön lisans düzeyinde ormancılık ve orman ürünleri öğrenim gören öğrencilerinin yaz stajıyla ilgili görüşlerini belirlemeye yönelik olarak yapılan bu araştırmada ankete katılan öğrencilerin kişisel özelliklerine ilişkin bilgiler Tablo 1'de sunulmuştur. 
Tablo 1. Ankete Katılan Öğrencilerin Bazı Demografik Özellikleri

\begin{tabular}{|c|c|c|c|}
\hline Kriterler & Değişkenler & Frekans & $\%$ \\
\hline \multirow{2}{*}{ Cinsiyet } & Kadın & 11 & 13,6 \\
\hline & Erkek & 70 & 86,4 \\
\hline \multirow{4}{*}{ Yaş aralığ1 } & $18-19$ & 26 & 32,1 \\
\hline & $20-21$ & 45 & 55,6 \\
\hline & $22-23$ & 6 & 7,4 \\
\hline & 24 ve üzeri & 4 & 4,9 \\
\hline \multirow{5}{*}{ Ailesinin ikamet ettiği bölge } & Akdeniz Bölgesi & 7 & 8,6 \\
\hline & Ege Bölgesi & 66 & 81,5 \\
\hline & Marmara Bölgesi & 5 & 6,2 \\
\hline & Doğu Anadolu Bölgesi & 1 & 1,2 \\
\hline & Karadeniz Bölgesi & 2 & 2,5 \\
\hline \multirow{3}{*}{ Mezun olunan lise türü } & Meslek Lisesi & 46 & 56,8 \\
\hline & Açık Öğretim Lisesi & 1 & 1,2 \\
\hline & Diğer & 34 & 42 \\
\hline \multirow{5}{*}{ Staj yapılan bölge } & Akdeniz Bölgesi & 6 & 7,4 \\
\hline & Ege Bölgesi & 67 & 82,7 \\
\hline & Marmara Bölgesi & 5 & 6,2 \\
\hline & Doğu Anadolu Bölgesi & 1 & 1,2 \\
\hline & Karadeniz Bölgesi & 2 & 2,5 \\
\hline \multirow{6}{*}{$\begin{array}{l}\text { Eğitim görülen programın } \\
\text { tercih edilme nedeni }\end{array}$} & Sınav düzenlemesinden dolayı & 8 & 9,9 \\
\hline & Sevdiğim için & 28 & 34,6 \\
\hline & Daha kısa sürede iş sahibi olabilmek için & 17 & 21,0 \\
\hline & Daha iyi bir iş sahibi olabilmek için & 16 & 19,8 \\
\hline & Çevrenin etkisi & 6 & 7,4 \\
\hline & İstek dişı & 6 & 7,4 \\
\hline
\end{tabular}

Ankete katılan öğrencilerin 70'i (\% 86,4) erkek, 11'i (\% 13,6) bayandır. Ankete katılan öğrencilerin 26'sı (\% 32,1) 18-19 yaş aralığında, 45'i (\% 55,6) 20-21 yaş aralığında, 6'sı (\% 7,4) 22-23 yaş aralığında ve 4'ü $(\%$ 4,9) 24 yaş ve üzerindedir. Öğrencilerin ikamet ettikleri bölgelere göre incelendiğinde ise, ilk sırayı \% 81,5 (66) oranıyla Ege Bölgesi'nin aldığı görülmektedir. Ankete katılan öğrencilerden hiçbiri İç Anadolu ve Güneydoğu Anadolu Bölgelerini işaretlememişlerdir. Dolayısıyla öğrenci sayısı "0" olan bu bölgeler tabloya alınmamıştır. Tablodaki diğer bölge oranlarıyla birlikte göz önüne alındığında ankete katılan öğrencilerin neredeyse tamamına yakınının Ege Bölgesi'nde ikamet ediyor olmaları nedeniyle meslek yüksekokulu öğrenci profilinin daha çok ikamet edilen bölgedeki illerden ya da yakın illerden oluştuğuna işaret ettiği söylenebilir. Ancak meslek yüksekokullarına sınavsız girişin de bu konuda etkili olduğu belirtilmesi gereken bir diğer husustur. Ankete katılan öğrencilerin 46’s (\% 56,8) meslek lisesi, 1’i (\% 1,2) Açık Öğretim Lisesi ve 34’ü (\% 42) diğer liselerden mezun olmuşlardır. Ankete katılan öğrencilerin 67'si (\% 82,7) Ege Bölgesinde, Akdeniz Bölgesinde, 5'i (\% 6,2) Marmara Bölgesinde, 2'si (\% 2,5) Karadeniz Bölgesinde ve 1'i (\% 1,2) Doğu Anadolu Bölgesinde staj yapmışlardır. Güneydoğu Anadolu Bölgesi ve İç Anadolu Bölgesi seçeneğini hiçbir öğrencinin işaretlemediği ve değerinin " 0 " olduğu görülmüş ve tabloya alınmamıştır. Genel olarak öğrencilerin ikamet yerleri ile staj yaptıkları bölgelerin birbirleriyle uygunluk içinde olduğu, yani öğrencilerin tamamına yakınının ikamet etkileri bölgede staj 
yaptıkları söylenebilir. Ankete katılan öğrencilerin 8'si $(\% 9,9)$ sinav düzenlemesinden dolayı, 28'i (\% 34,6) sevdiği için, 17'si (\% 21) daha kısa sürede iş sahibi olabilmek için, 16 'sı $(\% 19,8)$ daha iyi bir iş sahibi olabilmek için, 6's1 $(\% 7,4)$ çevrenin etkisi ile ve 6's1 $(\% 7,4)$ istek dışı eğitim gördükleri programı tercih ettiğini belirtmiştir.

Ankete katılan öğrencilerin staj eğitimi ile ilgili görüşlerine ilişkin ifadelere katılma derecelerinin frekans, yüzde, ortalama ve standart sapmaları Tablo 2'de verilmiştir.

Tablo 2. Ankete Katılan Öğrencilerin Staj Eğitimi İle İlgili Görüşleri

\begin{tabular}{|c|c|c|c|c|c|c|c|c|c|c|c|c|}
\hline IFADELER & Kat1 & orum & Katıl & rum & $\begin{array}{r}\text { K1s } \\
\text { Kat1l } \\
\end{array}$ & & Katılı & rum & $\begin{array}{r}\text { Tan } \\
\text { Katıl } \\
\end{array}$ & $\begin{array}{l}\text { hen } \\
\text { rum }\end{array}$ & N & SS \\
\hline Staj Eğitimi; & $\mathbf{f}$ & $\%$ & $\mathbf{f}$ & $\%$ & f & $\%$ & f & $\%$ & f & $\%$ & & \\
\hline $\begin{array}{l}\text { Staj Ormancılık ve } \\
\text { Orman Ürünleri } \\
\text { Programı için } \\
\text { önemli ve } \\
\text { gereklidir. }\end{array}$ & 2 & 2,5 & 2 & 2,5 & 2 & 2,5 & 19 & 23,5 & 56 & 69,1 & 4,54 & 87 \\
\hline $\begin{array}{l}\text { Staj yerlerini okul } \\
\text { bulmalıdır. }\end{array}$ & 33 & 40,7 & 14 & 17,3 & 11 & 13,6 & 8 & 9,9 & 15 & 18,5 & 2,48 & 1,55 \\
\hline $\begin{array}{l}\text { Staj süresi } 30 \text { gün } \\
\text { yeterlidir. }\end{array}$ & 5 & 6,2 & 4 & 4,9 & 10 & 12,3 & 26 & 32,1 & 36 & 44,4 & 4,04 & 1,15 \\
\hline $\begin{array}{l}\text { Staj yerleri okul } \\
\text { tarafından (bölüm } \\
\text { başkanı, } \\
\text { koordinatör, } \\
\text { danışman vb. } \\
\text { denetlenmelidir }\end{array}$ & 8 & 9,9 & 7 & 8,6 & 9 & 11,1 & 29 & 35,8 & 28 & 34,6 & 3,77 & 1,28 \\
\hline
\end{tabular}

Tablo 2 genel olarak incelendiğinde en yüksek aritmetik ortalama; "staj, ormancılık ve orman Ürünleri Programı için önemli ve gereklidir" $(X=4,54)$ ifadesinde gerçekleşmiştir. Aritmetik ortalamasının yüksek olduğu diğer bir ifade ise; "Staj süresi (30 gün) yeterlidir" (X =4,04) ifadesinde gerçekleşmiştir. En düşük aritmetik ortalama ise; "Staj yerlerini okul bulmalıdır" $(X=2,48)$ ifadesinde gerçekleşmiştir. Ayrıca araştırmaya katılan öğrencilerin yarıdan fazlası; staj yerleri okul tarafından (bölüm başkanı, koordinatör, danışman vb.) denetlenmelidir (katılıyorum \% 35,8, tamamen katılıyorum \% 34,6) belirtmişlerdir. Verilen cevaplardan da anlaşılacağı üzere ankete katılan öğrenciler staj eğitimini önemsemelerine rağmen, ankete katılan öğrencilerin 47 (\% 58) staj yapılacak kurumu kendilerinin bulması gerektiğini ifade ederken 23 'ü (\% $28,4)$ staj yapılacak kurumu okulun belirlemesi gerektiğini ifade etmişlerdir. Ayrıca öğrencilerin 62'si $(\% 76,5)$ staj süresini yeterli bulmaktadırlar.

Ankete katılan öğrencilerin staj eğitimi memnuniyetine ilişkin ifadelere katılma derecelerinin frekans, yüzde, ortalama ve standart sapmaları verilmiştir. 
Tablo 3. Ankete Katılan Öğrencilerin Staj Memnuniyetleri İle İlgili Görüşleri

\begin{tabular}{|c|c|c|c|c|c|c|c|c|c|c|c|c|}
\hline \multirow{2}{*}{$\begin{array}{c}\text { İFADELER } \\
\text { Staj Eğitimi; }\end{array}$} & \multicolumn{2}{|c|}{$\begin{array}{c}\text { Hiç } \\
\text { Katılmıyorum } \\
\end{array}$} & \multicolumn{2}{|c|}{ Katılmiyorum } & \multicolumn{2}{|c|}{$\begin{array}{c}\text { Kismen } \\
\text { Katıliyorum }\end{array}$} & \multicolumn{2}{|c|}{ Katılıyorum } & \multicolumn{2}{|c|}{$\begin{array}{c}\text { Tamamen } \\
\text { Katıliyorum }\end{array}$} & \multirow[t]{2}{*}{ 㸃 } & \multirow[t]{2}{*}{ SS } \\
\hline & $f$ & $\%$ & $f$ & $\%$ & $f$ & $\%$ & $f$ & $\%$ & $f$ & $\%$ & & \\
\hline $\begin{array}{l}\text { Staj zamanınızı } \\
\text { verimli bir şekilde } \\
\text { planlama ve } \\
\text { kullanma becerisi } \\
\text { kazandırmıştır. }\end{array}$ & 2 & 2,5 & 5 & 6,2 & 9 & 11,1 & 27 & 33,3 & 38 & 46,9 & 4,16 & 1,02 \\
\hline $\begin{array}{l}\text { Stajınız süresince } \\
\text { bulunduğunuz iş̧ } \\
\text { yerinde yeterli } \\
\text { ilgi gösterilmiştir. }\end{array}$ & 5 & 6,2 & 4 & 4,9 & 7 & 8,6 & 28 & 34,6 & 37 & 45,7 & 4,09 & 1,14 \\
\hline $\begin{array}{l}\text { Staj eğitimi ve iş } \\
\text { yeri uygulama } \\
\text { faaliyetleri } \\
\text { sırasında size } \\
\text { çalışma alanınız } \\
\text { dışında işler } \\
\text { yaptırıldı. }\end{array}$ & 39 & 48,1 & 15 & 18,5 & 5 & 6,2 & 9 & 11,6 & 13 & 16 & 2,28 & 1,54 \\
\hline $\begin{array}{l}\text { Staj yaptığınız } \\
\text { işletme staj } \\
\text { konusunda } \\
\text { beklentilerinizi } \\
\text { karşılamıştır. }\end{array}$ & 2 & 2,5 & 5 & 6,2 & 7 & 8,6 & 37 & 45,7 & 30 & 37,0 & 3,88 & 1,04 \\
\hline $\begin{array}{l}\text { Staj size zayıf } \\
\text { olduğunuz } \\
\text { alanları görme ve } \\
\text { bu konudaki } \\
\text { eksikliklerinizi } \\
\text { tamamlama } \\
\text { imkanı } \\
\text { sağlamıştır. }\end{array}$ & 1 & 1,2 & 4 & 4,9 & 16 & 19,8 & 34 & 42 & 26 & 32,1 & 3,99 & ,92 \\
\hline $\begin{array}{l}\text { Staj size } \\
\text { kendinize olan } \\
\text { güven } \\
\text { duygusunun } \\
\text { gelişmesine katkı } \\
\text { sağlamıştır. }\end{array}$ & 2 & 2,5 & 2 & 2,5 & 8 & 9,9 & 48 & 53,9 & 21 & 25,9 & 4,04 &, 83 \\
\hline
\end{tabular}

Tablo 3 incelendiğinde en yüksek aritmetik ortalama; “Staj zamanınızı verimli bir şekilde planlama ve kullanma becerisi kazandırmıştır" $(X=4,16)$ ifadesinde gerçekleşirken, en düşük aritmetik ortalama ise "Staj eğitimi ve iş yeri uygulama faaliyetleri sırasında size çalışma alanınız dışında işler yaptırıldı." $(X=2,28)$ ifadesinde gerçekleşmiştir. Ankete katılan öğrencilerin, staj zamanınızı verimli bir şekilde planlama ve kullanma becerisi kazandırmıştır sorusuna verdikleri cevapların değerlendirilmesi ile ilgili verilere bakarak öğrencilerin \% 80,2'si (\% 33,3' ü "katılıyorum", \%46,9'u "tamamen katıliyorum") olumlu cevap verirken, \% 8, 7 ise (\% 2,5'i “hiç katılmiyorum", \% 6,2'si “katılmıyorum) olumsuz cevap verdikleri görülmektedir. Ankete katılan toplam 81 öğrencinin 65'ine (\% 80,3) staj sirasında yeterli ilgi gösterilmiş ancak 9'una (\% 11,1) yeterli ilgi gösterildiği cevabını verdikleri 
görülmektedir. Staj eğitimi ve iş yeri uygulama faaliyetleri sırasında stajyerlere çalışma alanı dışında başka işler yaptırıldığı ifadesine öğrencilerin \% 66,6'sı (\% 48,'i “hiç katılmiyorum", \% 18,5'i "katılmiyorum") olumsuz cevap verdikleri yani toplam 81 öğrencinin $54^{\prime}$ ü staj süresince mesleki eğitim dışında herhangi bir iş yapmadıklarını belirtmişlerdir. Staj yaptıkları işletme öğrencilerin \%82,7'sinin (\% $45,7^{\prime} \quad \ddot{u}$ "katıliyorum", \%37'si "tamamen katıliyorum") staj konusundaki beklentilerini karşıladığı, ancak öğrencilerin \%8,7'sinin (\% 2,5'i "hiç katılmıyorum" \% 6,2'si "katılmıorum") staj konusundaki beklentilerini karşıladığı ifade etmişlerdir. Öğrencilerin, staj size zayıf olduğunuz alanları görme ve bu konudaki eksikliklerinizi tamamlama imkânı sağlamıştır sorusuna verdikleri cevapların değerlendirilmesi ile ilgili verilere bakarak öğrencilerin \% 74,1'i (\% 42'si “katılıyorum”, \% 32,'i “tamamen katılıyorum") olumlu cevabını verirken, öğrencilerin \%6,1'i (\% 1,2'si "hiç katılmıyorum", \% 4,9'u "katılmıyorum") olumsuz cevap verdikleri görülmektedir.

Ankete katılan öğrencilerin yapmış oldukları staj eğitiminin mesleki katkıları ile ilgili ifadelere katılma derecelerinin frekans, yüzde, ortalama ve standart sapmaları Tablo 4'de verilmiştir.

Tablo 4. Ankete Katılan Öğrencilerin Staj Eğitiminin Mesleki Katkıları İle İlgili Görüşleri

\begin{tabular}{|c|c|c|c|c|c|c|c|c|c|c|c|c|}
\hline \multirow{2}{*}{$\begin{array}{c}\text { IFADELER } \\
\text { Staj Eğitimi; }\end{array}$} & \multicolumn{2}{|c|}{$\begin{array}{c}\text { Hiç } \\
\text { Katılmiyorum }\end{array}$} & \multicolumn{2}{|c|}{ Katılmiyorum } & \multicolumn{2}{|c|}{$\begin{array}{c}\text { Kismen } \\
\text { Katıliyorum }\end{array}$} & \multicolumn{2}{|c|}{ Katılıyorum } & \multicolumn{2}{|c|}{$\begin{array}{c}\text { Tamamen } \\
\text { Katıliyorum }\end{array}$} & \multirow[t]{2}{*}{ 歨 } & \multirow[t]{2}{*}{ SS } \\
\hline & $\mathrm{f}$ & $\%$ & $\mathrm{f}$ & $\%$ & $\mathrm{f}$ & $\%$ & $f$ & $\%$ & $f$ & $\%$ & & \\
\hline $\begin{array}{l}\text { Staj eğitimi ve iş } \\
\text { yeri uygulama } \\
\text { faaliyetlerinde, } \\
\text { daha önce } \\
\text { aldığım teorik } \\
\text { eğitimi daha iyi } \\
\text { kavradım. }\end{array}$ & 3 & 3,7 & 5 & 6,2 & 14 & 17,3 & 32 & 39,5 & 27 & 33,3 & 3,93 & 1,05 \\
\hline $\begin{array}{l}\text { Staj size mesleki } \\
\text { problemleri } \\
\text { görme, ifade } \\
\text { etme ve çözme } \\
\text { becerisi } \\
\text { kazandırmıştır. }\end{array}$ & 2 & 2,5 & 3 & 3,7 & 7 & 8,6 & 35 & 43,2 & 34 & 42 & 4,19 & ,92 \\
\hline $\begin{array}{l}\text { Staj size mesleki } \\
\text { anlamda güncel } \\
\text { bilgiler } \\
\text { kazandırmıştır. }\end{array}$ & 2 & 2,5 & 4 & 4,9 & 3,7 & 7 & 38 & 46,9 & 34 & 42 & 4,21 & ,92 \\
\hline $\begin{array}{l}\text { Staj size eğitimi } \\
\text { aldığınız } \\
\text { mesleki } \\
\text { branşınız için } \\
\text { gerekli alet, } \\
\text { makine ve } \\
\text { ölçüm araçlarını } \\
\text { kullanma } \\
\text { becerisi } \\
\text { kazandırmıştır. }\end{array}$ & 4 & 4,9 & 5 & 6,2 & 8 & 9,9 & 28 & 34,6 & 36 & 44,4 & 4,07 & 1,12 \\
\hline
\end{tabular}


Tablo 4. Ankete Katılan Öğrencilerin Staj Eğitiminin Mesleki Katkıları İle İlgili Görüşleri (Devamı)

\begin{tabular}{|c|c|c|c|c|c|c|c|c|c|c|c|c|}
\hline \multirow{2}{*}{$\begin{array}{c}\text { IFADELER } \\
\text { Staj Eğitimi; }\end{array}$} & \multicolumn{2}{|c|}{$\begin{array}{c}\text { Hiç } \\
\text { Katılmiyorum }\end{array}$} & \multicolumn{2}{|c|}{ Katılmıyorum } & \multicolumn{2}{|c|}{$\begin{array}{c}\text { Kismen } \\
\text { Katıliyorum }\end{array}$} & \multicolumn{2}{|c|}{ Katılıyorum } & \multicolumn{2}{|c|}{$\begin{array}{c}\text { Tamamen } \\
\text { Katıliyorum }\end{array}$} & \multirow[t]{2}{*}{ at } & \multirow[t]{2}{*}{ SS } \\
\hline & $\mathrm{f}$ & $\%$ & $\mathrm{f}$ & $\%$ & $f$ & $\%$ & $f$ & $\%$ & $\mathrm{f}$ & $\%$ & & \\
\hline $\begin{array}{l}\text { Staj size mesleki } \\
\text { ve etik } \\
\text { sorumlulukları } \\
\text { anlama ve } \\
\text { uygulama } \\
\text { bilinci } \\
\text { vermiştir. }\end{array}$ & 1 & 1,2 & 3 & 3,7 & 10 & 12,3 & 44 & 54,3 & 23 & 28,4 & 4,05 & 82 \\
\hline $\begin{array}{l}\text { Staj size } \\
\text { ormancılık alanı } \\
\text { ile ilgili } \\
\text { gelişmeleri } \\
\text { uygulama } \\
\text { düzeyinde } \\
\text { görme imkânı } \\
\text { sağlamıştır. }\end{array}$ & 2 & 2,5 & 4 & 4,9 & 4 & 4,9 & 42 & 51,9 & 29 & 35,8 & 4,14 & ,90 \\
\hline $\begin{array}{l}\text { Staj size mezun } \\
\text { olduktan sonra } \\
\text { bu mesleği } \\
\text { yapma } \\
\text { düşüncenize } \\
\text { olumlu katkı } \\
\text { sağlamıştır. }\end{array}$ & 1 & 1,2 & 5 & 6,2 & 5 & 6,2 & 38 & 46,9 & 32 & 39,5 & 4,17 & ,89 \\
\hline $\begin{array}{l}\text { Staj size mesleki } \\
\text { anlamda } \\
\text { hedeflerinizi } \\
\text { belirleme } \\
\text { konusunda } \\
\text { katkı } \\
\text { sağlamıştır. }\end{array}$ & 1 & 1,2 & 2 & 2,5 & 10 & 12,3 & 41 & 50,6 & 27 & 33,3 & 4,12 & 81 \\
\hline $\begin{array}{l}\text { Staj size takım } \\
\text { çalışması } \\
\text { yürütme } \\
\text { becerisi } \\
\text { kazandırmıştır. }\end{array}$ & 2 & 2,5 & 5 & 6,2 & 7 & 8,6 & 37 & 45,7 & 30 & 37 & 4,09 & ,96 \\
\hline $\begin{array}{l}\text { Staj size mesleki } \\
\text { bilgileri } \\
\text { kullanma } \\
\text { becerisi } \\
\text { kazandırmıştır. }\end{array}$ & 2 & 2,5 & 3 & 3,7 & 7 & 8,6 & 33 & 40,7 & 36 & 44,4 & 4,21 & ,93 \\
\hline
\end{tabular}

Tablo 4 incelendiğinde en yüksek aritmetik ortalama "Staj size mesleki bilgileri kullanma becerisi kazandırmıştır" $(X=4,21)$ ifadesinde gerçekleşirken, en düşük aritmetik ortalama "Staj eğitimi ve iş yeri uygulama faaliyetlerinde, daha önce aldığım teorik eğitimi daha iyi kavradım" (X=3,93) ifadesinde gerçekleşmiştir. Genel olarak staj mesleki eğitim almış öğrencilere mesleki bilgileri kullanma becerisi kazandırmıştır. Nitekim ankete katılan öğrencilerin \% 85,1'i “Staj size mesleki bilgileri kullanma 
becerisi kazandırmıştır" ifadesine "katılıyorum" ve "tamamen katılıyorum" şeklinde olumlu düşüncelerini belirtmişlerdir. Ankete katılan öğrencilerin, "Staj eğitimi ve iş yeri uygulama faaliyetlerinde, daha önce aldığım teorik eğitimi daha iyi kavradım" sorusuna verdikleri cevapların değerlendirilmesi ile ilgili verilere bakarak öğrencilerin \% 85,1'i (\% 40,7'si "katıliyorum", \% 44,4'ü “tamamen katıliyorum") olumlu cevap verirken, \% 6,2'si (\% 2,5'i “hiç katılmıyorum", \% 3,7'si “katılmıyorum) ise olumsuz cevap verdikleri görülmektedir.

Ankete katılan öğrencilerin \% 72,8'i (\% 39,5'u “katılıyorum", \% 33,3'ü "tamamen katılıyorum") aldığı teorik eğitimi uygulama imkânı bulduğunu, \% 87,7'si (\%51,9'u “katılıyorum”, \% 35,8'i “tamamen katılıyorum") ormancilık alanı ile ilgili gelişmeleri uygulama düzeyinde görme imkânı bulduğunu, \% 86,4'ü (\% 46,9'u "katılıyorum", \% 39,5'i "tamamen katılıyorum") ormancılık bölümünden mezun olduktan sonra bu mesleği yapma düşüncesine katkı sağladığını belirtmişlerdir. Öğrencilerin \% 85,2'si (\%51,9'u “katıllyorum", \% 35,8'i “tamamen katılıyorum") mesleki problemleri görme, ifade etme ve çözme becerisi, \% 79'u (\% 34,6's1 "katılıyorum", \% 44'4'ü “tamamen katılıyorum") meslek branşlarında kullandıkları alet ve ölçüm cihazlarının kullanımı konusunda uygulama imkânı bulduklarını, \% 85,1'i ise (\% 40,7'si "katılıyorum", \% 44,4'ü “tamamen katıllyorum") mesleki bilgileri uygulama düzeyinde görme ve kullanma imkânı bulduklarını ifade etmişlerdir.

Öğrencilerin, \% 82,7'si (\% 54,3'ü “katıllyorum”, \% 28,4'ü “tamamen katılıyorum") mesleki ve etik sorumlulukları anlam ve uygulama bilinci verdiği ifadesine katıldıkları görülmekte, \%82,7'si (\% 45,7'si “katılıyorum”, \% 37'si “tamamen katılıyorum") mesleki alanda takım çalışması yürütme becerisi kazandıklarını, \%82,9'u (\% 46,9'u "katılıyorum", \% 42'si "tamamen katılıyorum") mesleki alanda güncel bilgiler kazandıklarını ve \%83,9'u (\% 50,6'si "katılıyorum", \% 33,3'ü "tamamen katılıyorum") mesleki alanda hedefleri belirleme konusunda katkı sağladığını belirtmişlerdir.

\section{SONUÇ VE TARTIŞMA}

$\mathrm{Bu}$ çalışma, Uşak Üniversitesi Banaz Meslek Yüksekokulu'nda I.ve II. öğretimde Ormancılık ve Orman Ürünleri programında öğrenim gören, staj eğitimini tamamlamış 81 öğrenciye uygulanan anket çalışması neticesinde hazırlanmıştır. Katılımcılara ilk aşamada demografik bilgiler, ikinci aşamada ise araştırmaya katılan öğrencilerin staj eğitimi, staj memnuniyetleri ve staj eğitiminin mesleki katkıları ile ilgili görüşleri tespit edilmeye çalışılmıştır. Tüm test sonuçları SPSS 20.0 istatistiksel analiz programlarında değerlendirilmiş, elde edilen bulgular frekans analizi uygulanarak değerlendirilmiştir. Araştırma sonucunda elde edilen önemli sonuçlar şunlardır:

Öğrencilerin öğrenim gördükleri programı tercih etme nedenleri içinde sevdikleri için \% 34,6'lık oranla birinci sırayı alırken, \% 21'lik oranla ikinci sırayı daha kısa sürede iş bulabilmek için, 19,8'lik oranla üçüncü sırayı daha iyi bir iş sahibi olabilme nedenleri almaktadır. Sınav düzenlemesinden dolayı ise \% 9,9'luk oranla dördüncü sırayı almıştır. Sonuçlar dikkate alındığında kısa sürede iş sahibi olabilmek 
ve daha iyi iş sahibi olabilmek için programda okuyan öğrencilerle mesleği sevdiği için programda okuyan öğrencilerin oranlarının aynı denebilecek kadar birbirine yakın olmasından hareketle de, öğrencilerin mesleği sevme isteğinin, iş hayatına daha çabuk atılabilme isteklerinin daha önünde olduğunu ifade etmek yanlış olmaz. Diğer taraftan staj yapılan yer ile ilgili olarak araştırma değerlendirildiğinde genelde staj yerinin ikamet edilen bölge ile aynı olduğu sonucu ortaya çıkmıştır.

Ankete katılan öğrencilerin büyük bir bölümü tarafından (\% 58'i) staj yapılacak kurumu kendilerinin belirlemesi gerektiğini belirtmişlerdir. Aydemir (2016) tarafından önlisans düzeyinde sağlık hizmetleri eğitimi alan öğrencilerin yaz stajı uygulamaları ile ilgili görüşlerini değerlendirmeye yönelik yapılan çalışmada ise araştırmaya katılan öğrencilerin tamamına yakını (\%91,1'i) staj yapılacak kurumu kendileri tarafından bulunması gerektiğini ifade etmişlerdir.

Ankete katılan öğrencilerin büyük bir bölümünün (\% 70,4'ü) stajları daha etkin hale getirmek için denetimin olması gerektiğini ifade ettikleri tespit edilmiştir. Uzun vd. (2009) tarafından Düzce Üniversitesi Peyzaj Mimarlığı Bölümü öğrencilerinin stajdan işverenin ise öğrenciden beklentilerinin değerlendirilmesi amacıyla yapılan çalışmada ise ankete katılan öğrencilerin \% 83,3'ünün yapılan stajlara ilişkin olarak denetim yapılmasını istedikleri rapor edilmiştir.

Ankete katılan öğrencilerin tamamına yakını (\% 92,6'sı) staj eğitiminin gerekli ve önemli olduğunu, öğrencilerin büyük bir bölümünün (\% 88,9'u) stajın mesleki anlamda güncel konular hakkında bilgi sağladığı belirtmişlerdir. Bahadır ve Oğuz (2012) tarafından teknik bilimler meslek yüksekokulu öğrencilerinin staj yapma eğilimlerinin belirlenmesine yönelik yapılan çalışmada araştırmaya katılan öğrencilerin tamamına yakını (\%89,5'i) stajın mesleki anlamda güncel bilgiler kazandırdığını ifade etmişlerdir.

Ankete katılan öğrencilerin (\% 87,7'si) ormancılık alanı ile ilgili gelişmeleri uygulama düzeyinde görme imkânı sağladığını, öğrencilerin büyük bir bölümü tarafından (\% 86,4'ü ) staj eğitiminin gelecekte iş yaşamlarına yön verme konusunda fikir verdiği, öğrencilerin büyük bir bölümünün (\% 85,2'si) stajın mesleki problemleri görme, ifade etme ve çözme becerisi kazandırdığını belirtmişlerdir. Bahadır ve Oğuz (2012) tarafından yapılan bir çalışmada ise ankete katılan öğrencilerin tamamına yakını (\% 91,2'si) stajin mesleki alanda mesleki problemleri görme, ifade etme ve çözme becerisi kazandırdığını ifade etmişlerdir.

Ankete katılan öğrencilerin büyük bir çoğunluğu tarafından (\%85,1'i) stajın mesleki bilgileri kullanma becerisi kazandırdığını belirtmişlerdir.

Stajı eğitimini tamamlayan öğrencilerin büyük bir çoğunluğunun stajdan olumlu sonuçlar aldığı ancak bu olumluluğun aslında uygun staj yerlerinin seçimi ve denetimin sağlanmasına bağlı olduğunu görülmektedir.

Bu çalışmadan çıkan sonuçlar doğrultusunda, üniversite düzeyinde ormancılık eğitimi veren okullardaki staj faaliyetlerinin tüm tarafların beklentilerini karşılayacak 
şekilde düzenlemelerine katkı sağlayacak belli başlı önerileri şu şekilde sıralamak mümkündür:

Öğrencilerin staj eğitimleri boyunca koordinatör öğretim elemanı tarafından denetlenmesi, staj eğitimi öncesi bilgilendirme toplantılarının hem okul hem de iş yeri tarafından yapılması gerekmektedir.

Öğrencilerin eğitim görecekleri departmanlar ve bu departmanlarda öğrencinin beceri eğitimi ile ilgilenecek personel, stajyerin tanımı ve eğitimi konusunda bilgilendirilmeli, öğrenci başka amaçlarla o birimde bulunmamalıdır.

Üniversite düzeyindeki ormancılık eğitim müfredatlarında sektörle ilgili uygulama derslerine yer veriliyor olsa da staj; öğrencilerin çalışma hayatını yerinde görmeleri ve uygulama derslerinde edindikleri pratik bilgileri uygulamaya geçirme fırsatı bulmaları bakımından önemli bir faaliyettir. Bu kapsamda özellikle eğitim kurumları, stajın ileride meslek yaşamında referans sağlayacak önemli bir faaliyet olduğunun bilincini öğrencilere vermelidirler. Bu durum öğrencilerin staja ilişkin ön yargılarını da ortadan kaldırmaya katkı sağlayacaktır.

Meslek yüksekokullarında gösterilen müfredatlar günün koşulları ve teknolojik değişimler sonrasında güncellenmeli, iş yerleri ve eğitim kurumları bu doğrultuda paralel hareket etmelidir.

Ormancılık eğitim kurumlarında görevlendirilen staj komisyon üyelerinin, işletmelerle sözleşme yapma, staj şartlarını ayarlama, eğitim kurumları ile işletmeler arasında koordinasyonu sağlamada etkin rol oynayabilmeleri için yetkilerinin artırılması gerekmektedir.

Öğrencilerin orman işletmelerinde yaptıkları/yapacakları staj faaliyetlerini gereksiz görmelerine neden olan işletmeler ve eğitim kurumlarından kaynaklanan sorunlara (stajyerin ucuz işgücü olarak görülmesi, sosyal güvenlik imkânları, hizmet içi eğitim, stajyerlerin barınma sorunları vb.) ilişkin orman işletme müdürlükleri ve eğitim kurumlarından oluşan ortak komisyonlar kurularak çözüm önerileri geliştirilmelidir. Staj anlaşması yapılacak işletmelerde uyumlaştırma, rotasyon, hizmet içi eğitim, ücret düzeyi, çalışma saatleri kıstaslarına bakılmalı ve staj anlaşmasının içeriğinde bu kıstaslara yer verilmelidir.

Burada önemli olan mesleğini seven öğrencilerle daha verimli çalışılacağı ve mezun olduktan sonra da mesleklerini seven insanların iş hayatında daha başarılı oldukları gerçeğidir. Geliştirilen yöntemler ile kamu ve özel sektörden sağlanacak desteklerle, öğrencilerin iş hayatına daha uygun şekilde yetiştirilmeleri sağlanmalı, özellikle piyasaya ara eleman yetiştirme görevi üstlenmiş olan meslek yüksekokullarımızın ormancılık ve orman ürünleri programları bu çerçevede yenilenerek çağın gereklerine uygun hale getirilmesi gerekmektedir. 


\section{KAYNAKÇA}

Aydemir. D.H. (2016). Meslek Yüksekokulu Öğrencilerinin Yaz Stajı Eğitimine Yönelik Görüşlerinin Belirlenmesi, Türk Yaşam Bilimler Dergisi, 1(1): 34-42.

Aymankuy, Y., Tetik, N., Girgin, G.K. ve Aymankuy, Ş. (2013). Lisans Düzeyinde Turizm Eğitimindeki Staj Uygulamasına Öğrenci ve Akademisyenlerin Bakışları (BTíOYO'da Uygulama), International Journal of Human Sciences, 10 (1): 102-124

Bahadır, M. ve Oğuz, H. (2012). Selçuk Üniversitesi Teknik Bilimler Meslek Yüksekokulu Öğrencilerinin Staj Yapma Eğilimlerinin Belirlenmesi, Iğdır Üniversitesi Fen Bilimleri Enstitüsü Dergisi, 2(2, Ek: A): 69-76.

Çetin, Ş. (2005). Öğrenci Stajlarında Yararlanılan Dersler Üzerine Ampirik Bir Değerlendirme: Mersin Turizm İşletmeciliği ve Otelcilik Yüksekokulu Örneği. Anatolia, Turizm Araştırmaları Dergisi, 16(2): 153-169.

Demir, M. (2001). Meslek Yüksekokullarında Staj Çalışmalarının Değerlendirilmesine Yönelik Bir Anket Uygulaması, Muhasebe ve Finansman Dergisi, Sayı 11: 71-79.

Doğan, H., Ulusoy A. ve Hacıoğlu, F. (1997). Okul Sanayi İlişkileri, Okuldan İş Hayatına Geçiş. Ankara: Önder Matbaacllı.

Dilay, Y., Özkan, A. ve Kilit M. (2015). Karamanoğlu Mehmetbey Üniversitesi Teknik Bilimler Meslek Yüksekokulu Makine Programı Öğrencilerinin Staj Yapma Eğilimlerinin Belirlenmesi, 4 th International Vocational Schools Symposium, Yalova Üniversitesi, 18.

Emir, O., Arslan, S. ve Kılıçkaya S. (2008). Turizm İşletmeciliği Programı Öğrencilerinin Staj Uygulamaları Hakkındaki Görüşlerinin Değerlendirilmesi: Afyon Kocatepe Üniversitesi Örneği. Afyon Kocatepe Üniversitesi IIBF Dergisi, 10(2): 273-291.

Hsu, M.S. (2012). A Study of Internship Attitude, Subjective Norm, Perceived Behavioral Control and Career Planning of Hospitality Vocational College Students. Journal of Hospitality, Leisure, Sport Tourism Education. 11(1): 5-11.

Karacan, S. ve Karacan, E. (2004). Meslek Yüksekokullarında (MYO) Yapılan Staj Uygulamalarına İlişkin Bir Araştırma: Kalite Ve Verimlilik İçin İş Yerleri-MYO İşbirliğinin Gereği. Kocaeli Üniversitesi Sosyal Bilimler Enstitüsü Dergisi, (8)2: 168-184.

MEB-YÖK (2002). Meslek Yüksekokulları Program Geliştirme Projesi, Ankara.

Şengel, S. (2002). Meslek Yüksekokulları Muhasebe Programları Öğrenci Profili Üzerine Bir Araştırma, Muhasebe Bilim Dünyası Dergisi, 4(1): 121-133.

Şimşek, E. ve Özlem, Ç. (2004). Sosyal Bilimler Alanındaki Meslek Yüksekokullarının Staj Yükü Muhasebe Bürolarında, Muhasebe ve Denetime Bakış, 4(11): 101-115.

Pelit, E. ve Güçer, E. (2006). Turizm Alanında Öğretmenlik Eğitimi Alan Öğrencilerin Turizm İşletmelerinde Yaptıkları Stajları Değerlendirmeleri Üzerine Bir Araştırma. Gazi Üniversitesi Ticaret ve Turizm Eğitim Fakültesi Dergisi, 1(1) : 139-164.

Taşkın, M. (2006). Ortaöğretim Turizm Eğitiminde Staj ve İzmir İli Anadolu Otelcilik Turizm Meslek Liselerinde Bir Uygulama (Yayımlanmamış Yüksek Lisans Tezi). İzmir: Dokuz Eylül Üniversitesi Sosyal Bilimler Enstitüsü. 
Tekbalkan, M. (2015). Önlisans Düzeyinde Turizm Eğitimindeki Staj Uygulamasına Yönelik Öğrencilerin Bakışları: Ondokuz Mayıs Üniversitesi'nde Bir Uygulama, 4 th International Vocational Schools Symposium, Yalova Üniversitesi, 346-356.

Uzun, O., Köylü, P., Demir, Z., Müderrisoğlu, H., Karadağ. A.A., Özkan, A.Ş., Uzun, S., Girti, P. ve Kesim, G.A. (2009). Peyzaj Mimarlığı Eğitiminde Stajın Öğrenci Ve İşveren Açısından Değerlendirilmesi; Düzce Üniversitesi Peyzaj Mimarlı̆̆ı Bölümü Örneği, Bartın Orman Fakültesi Dergisi, Özel Sayı, 1. Batı Karadeniz Ormancılık Kongresi Bildiriler Kitabı, Bartın, Cilt II: 519-531. 